\title{
Ethephon Treatment May Alleviate the Suppression of Female Flowers of Cucurbita Pepo under High Temperatures
}

\author{
H.C. Wien \\ Department of Horticulture, Cornell University, Ithaca, NY 14853
}

Additional index words. sex expression, ethylene inhibitor, screening technique, silver thiosulfate

\begin{abstract}
When pumpkins are grown in elevated temperatures $\left(32 / 27^{\circ} \mathrm{C}\right.$ day/night) for 1 week during flower development, fewer female flower buds are formed than at normal temperatures $\left(20 / 15{ }^{\circ} \mathrm{C}\right)$ and only a small percentage of these reach anthesis. To determine if application of the ethylene-releasing compound ethephon can overcome the suppression of female flowers at high temperatures, 'Baby Bear' pumpkin plants were sprayed at the two-leaf stage with 100 or $300 \mu \mathrm{L} \cdot \mathrm{L}^{-1}$ ethephon and then grown in hot and cool greenhouse compartments. At $20 / 15{ }^{\circ} \mathrm{C}, 17 \%$ of the first 15 main stem nodes produced female flower buds on control plants and virtually all of these developed into open flowers. The higher rate of ethephon increased female bud percentage to $37 \%$. At $32 / 27^{\circ} \mathrm{C}$, only $3 \%$ of the nodes formed female flower buds and $2 \%$ flowered. Application of ethephon did not significantly increase female expression at high temperature, and none of the buds reached anthesis. Treatment with the inhibitor of ethylene action silver thiosulfate reduced female flower bud formation at the low temperature and entirely suppressed female flower buds at high temperature. In two additional experiments, these treatments were applied to two cultivars grown at a less extreme $32 / 20$ and at $20 / 15{ }^{\circ} \mathrm{C}$. Female buds and open flowers were moderately increased by ethephon in the high temperatures, suggesting that ethephon might foster female flowering in less extreme temperatures. Further work is needed to determine if ethephon treatment can overcome the heat-induced inhibition of female flowers in pumpkin under field conditions.
\end{abstract}

The main production areas for pumpkins (Cucurbita pepo L.) are the central and northern regions of the United States (Peirce, 1987). This implies that pumpkins most often flower and produce fruit in moderate temperatures. When grown in warmer conditions, female flowers are suppressed (Nitsch et al., 1952; Wien et al., 2004) as a result of a reduction in female flower bud formation and a failure of these buds to come to anthesis (Wien et al., 2004).

The plant hormone ethylene appears to play several roles in plants, and some of these conflict in the cucurbit vegetables. Its central role in formation of female flowers in some cucurbits has been known since the 1960s (Rudich et al., 1969). Breeders make use of this fact by applying the ethylene-releasing compound ethephon (2-chloroethane phosphonic acid) to seedlings of Cucumis and Cucurbita to enhance female flowering and suppress male blossoms in hybrid seed production (George, 1985). Further support for ethylene's role in sex expression comes from the finding that inhibitors of ethylene action such as silver thiosulfate delay female flower

Received for publication 10 Apr. 2006. Accepted for publication 29 June 2006. The technical assistance of Paul Cady and Katherine Shearman is gratefully acknowledged.

To whom reprint requests should be addressed; e-mailhcw2@cornell.edu. production in some cucurbits (Den Nijs and Visser, 1980). However, in watermelon (Citrullus lanatus), even low levels of applied ethylene suppress female tendency (Christopher and Loy, 1982). In addition, ethylene functions as a stress hormone in many plants and is generated in the plant under stresses such as elevated temperature and drought (Abeles et al., 1992).

Given the contradictory roles of ethylene in cucurbits, the present experiments were conducted to see if the reduction in female flower production during high temperatures could be counteracted by treatment of the plants with ethephon. If ethylene acts as a stress hormone in pumpkin grown at high temperatures, treatment with an inhibitor of ethylene may reduce deleterious effects.

\section{Materials and Methods}

In the first two experiments, pumpkin seeds (cv. Baby Bear, Johnnyseeds.com) germinated in paper towels were planted in $15-\mathrm{cm}$ diameter plastic pots filled with peatvermiculite soilless mix and placed in two greenhouse compartments set at 20/15 (day/ night) and $32 / 27^{\circ} \mathrm{C}$, respectively. When two true leaves had reached $2.5-\mathrm{cm}$ diameter, seedlings were sprayed to runoff with aqueous solutions of the following: 1) water (control); 2) $100 \mu \mathrm{L} \cdot \mathrm{L}^{-1}$ ethephon; 3) 300 $\mu \mathrm{L} \cdot \mathrm{L}^{-1}$ ethephon; 4) $1 \mathrm{~mm} \mathrm{Ag}+$ silver thio- sulfate; and 5) $5 \mathrm{~mm} \mathrm{Ag}+$ silver thiosulfate+. Silver thiosulfate was composed of a $1: 4 \mathrm{M}$ ratio of silver nitrate and sodium thiosulfate. A wetting agent $(0.1 \%$ liquid detergent) was added to all solutions. Within each temperature compartment, pots were arranged in five randomized blocks on the greenhouse bench with one plant per spray treatment per block spaced $45 \times 100 \mathrm{~cm}$ apart. The experiment was conducted twice, once beginning in early June and once in mid-Sept. 2002.

A second set of experiments applied similar treatments to two cultivars of pumpkin, 'Baby Bear' and 'Schooltime' (Stokeseeds. com). Plants were again grown at $20 / 15^{\circ} \mathrm{C}$ and at a more moderate $32 / 20^{\circ} \mathrm{C}$ temperature. Plants were treated with aqueous sprays at the two-leaf stage with 1) water; 2) $150 \mu \mathrm{L} \cdot \mathrm{L}^{-1}$ ethephon; 3) $300 \mu \mathrm{L} \cdot \mathrm{L}^{-1}$ ethephon; 4) $2.5 \mathrm{~mm}$ $\mathrm{Ag}+$ silver thiosulfate+; and 5) $5 \mathrm{~mm} \mathrm{Ag+}$ silver thiosulfate. Observations on the plants were the same as those taken in the initial experiments. There were six plants per treatment arranged in a randomized complete block design in each temperature compartment. The experiment was conducted twice starting in late March and late June 2003.

In all experiments, plants were observed between 35 and $50 \mathrm{~d}$ after sowing for formation and anthesis of female flowers and location on the main stem of these reproductive structures.

Results of both sets of experiments were statistically analyzed by calculating means and standard errors, because many zero values occurred at the higher temperature, and the temperature treatments were not replicated.

\section{Results and Discussion}

Under conditions of the first experiments, 'Baby Bear' pumpkins grown in moderate temperatures $\left(20 / 15^{\circ} \mathrm{C}\right)$ produced the first female flower buds at node 8 (Table 1). Application of ethephon in the two-leaf stage lowered location of female buds to node 6 , whereas treatment with silver thiosulfate (STS), an ethylene action inhibitor, displaced the first females to nodes 10 to 13 .

When the plants were grown at $32 / 27^{\circ} \mathrm{C}$, female primordia development was displaced to later nodes substantiating the results of previous greenhouse and field research (Wien et al., 2004). Plant reaction to ethephon application at the high temperatures was variable with some plants stimulated to produce female flower buds at lower nodes and others not so that position of the first female bud was not significantly different from the controls. The effect of STS at high temperatures was also not significantly different from control values.

When plants were grown at moderate temperatures, ethephon application increased the proportion of female flower buds and flowers reaching anthesis on the first 15 nodes (Table 1). The application of STS, especially at the higher concentration, reduced the number of female buds and flowers, confirming the important role of ethylene in pumpkin flower sex expression. At high temperatures, flower bud and flower production was 
drastically reduced in all treatments with little difference among treatments.

In the second set of experiments, both varieties of pumpkins grown at $20 / 15{ }^{\circ} \mathrm{C}$ reacted to ethylene and its inhibitor in a manner similar to the first experiments (Tables 2, 3, and 4). Ethephon application lowered and STS treatment slightly increased the node to first female bud. Ethephon increased both the percentage of female buds and female flowers on the first 15 nodes, whereas STS in these experiments caused a significant diminution of female tendency (Tables 3 and 4).

In contrast to the first experiments, ethephon stimulated female expression at the more moderate high temperatures used here ( $32 / 20$ versus $32 / 27$ in the first experiments). Silver thiosulfate on the other hand did not affect female flower bud and flower development differently than occurred in the high temperature controls.

The two cultivars Baby Bear and Schooltime reacted similarly to ethephon and STS treatments both at moderate and elevated temperatures, although Schooltime was reputed to have superior fruiting ability under elevated temperatures (D. Groff, personal communication). Differences in response to ethephon have been found among cultivars in $C$. pepo, but these lines have differed markedly in flowering pattern such as 'Vegetable Spaghetti' and 'Table Queen' (Edelstein et al., 1985). It remains to be seen if differences in ethephon response can be found among cultivars within the pumpkin plant and flowering type.

These experiments indicate that ethephon applications only overcome the heat-induced inhibition of female flowers in pumpkin at moderately elevated temperatures. Both cultivars showed some tendency for increased female flowering at the $32 / 20^{\circ} \mathrm{C}$ temperatures used in the later trials, but at the $32 / 27^{\circ} \mathrm{C}$ used in the initial experiments, the ethephon treatment effect was not evident. The experiments should be repeated under the summer field conditions of elevated temperatures as found in the southern states of the United States.

In many crops, ethylene functions as a stress hormone generated by the plant under conditions of elevated temperature, drought, anoxic conditions, and a host of other abiotic factors (Abeles et al., 1992). Such reactions have been documented for cucumber, for instance, in which exposure to a heat shock of $50{ }^{\circ} \mathrm{C}$ for $40 \mathrm{~s}$ resulted in a pronounced rise in ethylene $6 \mathrm{~h}$ later (Stermer and Hammerschmidt, 1985). It is not known if longer durations of more moderately elevated temperatures also cause cucurbit seedlings to generate ethylene. The results of the present experiments indicate that even if such treatments cause increased ethylene production by pumpkin seedlings growing at high temperatures, endogenous ethylene, and that generated by the plant when ethephon is applied did not stimulate an increase in female tendency. Furthermore, because the application of the ethylene action inhibitor STS to pumpkins grown at high temperatures did not increase female tendency, it is tempting to conclude that ethylene was not inhibiting female flowers under
Table 1. Effect of ethephon and the ethylene action inhibitor silver thiosulfate (STS) on location of the first female bud, the percent of female nodes, and the percent of female flowers on the first 15 nodes of the main stem grown in two temperature regimes in two greenhouse experiments with 'Baby Bear' pumpkin. ${ }^{\mathrm{z}}$

\begin{tabular}{|c|c|c|c|c|c|c|}
\hline \multirow[b]{2}{*}{ Treatment } & \multicolumn{2}{|c|}{$\begin{array}{l}\text { Node of first female } \\
\text { flower bud }\end{array}$} & \multicolumn{2}{|c|}{$\begin{array}{l}\text { Female flower } \\
\text { buds }(\%)\end{array}$} & \multicolumn{2}{|c|}{$\begin{array}{c}\text { Female } \\
\text { flowers }(\%)\end{array}$} \\
\hline & $20 / 15$ & $32 / 27$ & $20 / 15$ & $32 / 27$ & $20 / 15$ & $32 / 27$ \\
\hline Water & $8.5 \pm 0.5^{y}$ & $19.8 \pm 4.3$ & $16.7 \pm 3.5$ & $3.3 \pm 5.6$ & $16.0 \pm 3.4$ & $2.7 \pm 4.6$ \\
\hline Ethephon, $100 \mu \mathrm{L} \cdot \mathrm{L}^{-1}$ & $6.5 \pm 0.7$ & $14.4 \pm 7.3$ & $20.0 \pm 4.7$ & $4.0 \pm 4.7$ & $15.3 \pm 6.3$ & $2.7 \pm 4.6$ \\
\hline Ethephon, $300 \mu \mathrm{L} \cdot \mathrm{L}^{-1}$ & $6.0 \pm 0.5$ & $15.8 \pm 8.2$ & $36.7 \pm 10.5$ & $4.0 \pm 4.7$ & $28.7 \pm 5.5$ & 0 \\
\hline STS, $1 \mathrm{~mm} \mathrm{Ag+}$ & $10.0 \pm 2.5$ & $20.5 \pm 2.7$ & $15.3 \pm 6.3$ & $0.7 \pm 2.1$ & $13.3 \pm 6.3$ & 0 \\
\hline STS, $5 \mathrm{~mm} \mathrm{Ag+}$ & $13.0 \pm 0.9$ & $21.5 \pm 1.8$ & $10.0 \pm 3.5$ & 0 & $10.0 \pm 3.5$ & 0 \\
\hline
\end{tabular}

${ }^{\mathrm{z}}$ Data are averages of the results of two experiments.

${ }^{\mathrm{y}}$ Mean $\pm \mathrm{SE}$ for five replications.

Table 2. Node of first female flower bud of two pumpkin cultivars, as influenced by the application of foliar sprays of ethephon, and the inhibitor of ethylene action STS and by subsequent growth under 32/20 or $20 / 15^{\circ} \mathrm{C}$ day/night temperatures. ${ }^{\mathrm{z}}$

\begin{tabular}{|c|c|c|c|c|}
\hline \multirow[b]{2}{*}{ Treatment } & \multicolumn{2}{|c|}{ Baby Bear } & \multicolumn{2}{|c|}{ Schooltime } \\
\hline & $20 / 15$ & $32 / 20$ & $20 / 15$ & $32 / 20$ \\
\hline Water & $10.4 \pm 2.3^{y}$ & $15.8 \pm 2.6$ & $10.6 \pm 2.5$ & $16.5 \pm 1.2$ \\
\hline Ethephon, $150 \mu \mathrm{L} \cdot \mathrm{L}^{-1}$ & $7.4 \pm 1.4$ & $9.8 \pm 4.1$ & $7.7 \pm 1.1$ & $8.3 \pm 3.4$ \\
\hline Ethephon, $300 \mu \mathrm{L} \cdot \mathrm{L}^{-1}$ & $6.8 \pm 1.2$ & $8.8 \pm 3.3$ & $7.0 \pm 1.0$ & $6.9 \pm 1.1$ \\
\hline STS, 2.5 mм Ag+ & $11.8 \pm 2.8$ & $17.0 \pm 1.9$ & $14.4 \pm 2.2$ & $17.4 \pm 2.4$ \\
\hline STS, $5 \mathrm{~mm} \mathrm{Ag+}$ & $13.3 \pm 2.6$ & $17.6 \pm 1.7$ & $13.9 \pm 2.7$ & $18.7 \pm 1.4$ \\
\hline
\end{tabular}

${ }^{\mathrm{z}}$ Data are averages of the results of two experiments.

${ }^{\mathrm{y}}$ Mean \pm SE for six replications.

Table 3. Percent female buds in the first 15 nodes of two pumpkin cultivars, as influenced by the application of foliar sprays of ethephon and the inhibitor of ethylene action STS, and by subsequent growth under $32 / 20$ or $20 / 15{ }^{\circ} \mathrm{C}$ day/night temperatures. ${ }^{\mathrm{z}}$

\begin{tabular}{|c|c|c|c|c|}
\hline \multirow[b]{2}{*}{ Treatment } & \multicolumn{2}{|c|}{ Baby Bear } & \multicolumn{2}{|c|}{ Schooltime } \\
\hline & $20 / 15$ & $32 / 20$ & $20 / 15$ & $32 / 20$ \\
\hline Water & $12.2 \pm 4.8^{y}$ & $2.8 \pm 4.4$ & $11.1 \pm 4.3$ & $1.1 \pm 2.6$ \\
\hline Ethephon, $150 \mu \mathrm{L} \cdot \mathrm{L}^{-1}$ & $18.3 \pm 7.6$ & $11.1 \pm 8.2$ & $20.0 \pm 4.0$ & $15.0 \pm 8.6$ \\
\hline Ethephon, $300 \mu \mathrm{L} \cdot \mathrm{L}^{-1}$ & $25.6 \pm 6.8$ & $13.3 \pm 8.0$ & $30.0 \pm 3.4$ & $23.3 \pm 8.3$ \\
\hline STS, $2.5 \mathrm{~mm} \mathrm{Ag+}$ & $10.6 \pm 5.3$ & $0.6 \pm 1.9$ & $5.0 \pm 4.1$ & $1.1 \pm 2.6$ \\
\hline $\mathrm{STS}, 5 \mathrm{~mm} \mathrm{Ag}+$ & $6.7 \pm 5.7$ & $0.6 \pm 1.9$ & $5.0 \pm 4.1$ & 0 \\
\hline
\end{tabular}

${ }^{2}$ Data are averages of the results of two experiments.

${ }^{\mathrm{y}}$ Mean $\pm \mathrm{SE}$ of six replications.

Table 4. Percent female flowers on the first 15 nodes of two pumpkin cultivars, as influenced by the application of foliar sprays of ethephon and the inhibitor of ethylene action STS, and by subsequent growth under $32 / 20$ or $20 / 15^{\circ} \mathrm{C}$ day/night temperatures. ${ }^{\mathrm{z}}$

\begin{tabular}{|c|c|c|c|c|}
\hline \multirow[b]{2}{*}{ Treatment } & \multicolumn{2}{|c|}{ Baby Bear } & \multicolumn{2}{|c|}{ Schooltime } \\
\hline & $20 / 15$ & $32 / 20$ & $20 / 15$ & $32 / 20$ \\
\hline Water & $11.6 \pm 5.0^{y}$ & $2.8 \pm 4.4$ & $9.4 \pm 5.3$ & $0.6 \pm 1.9$ \\
\hline Ethephon, $150 \mu \mathrm{L} \cdot \mathrm{L}^{-1}$ & $12.2 \pm 7.4$ & $5.6 \pm 6.9$ & $17.8 \pm 5.2$ & $14.4 \pm 8.9$ \\
\hline Ethephon, $300 \mu \mathrm{L} \cdot \mathrm{L}^{-1}$ & $18.9 \pm 10.2$ & $5.6 \pm 8.0$ & $27.8 \pm 5.5$ & $18.3 \pm 12.4$ \\
\hline STS, $2.5 \mathrm{~mm} \mathrm{Ag+}$ & $10.0 \pm 5.3$ & 0 & $2.8 \pm 3.4$ & $1.1 \pm 2.6$ \\
\hline STS, $5 \mathrm{~mm} \mathrm{Ag+}$ & $5.6 \pm 5.6$ & 0 & $4.4 \pm 4.3$ & 0 \\
\hline
\end{tabular}

${ }^{\mathrm{z}}$ Data are averages of the results of two experiments.

${ }^{\mathrm{y}}$ Mean $\pm \mathrm{SE}$ for six replications.

those conditions. Further studies are needed to determine the production and fate of stressgenerated ethylene in pumpkins and other cucurbits.

\section{Literature Cited}

Abeles, F.B., P.W. Morgan, and M.E. Saltveit, Jr. 1992. Ethylene in plant biology 2nd ed., p. 83101 Academic, San Diego.

Christopher, D.A. and J.B. Loy. 1982. Influence of foliarly applied growth regulators on sex expression in watermelon. J. Amer. Soc. Hort. Sci. 107:401-404

Den Nijs, A.P.M. and D.L. Visser. 1980. Induction of male flowering in gynoecious cucumbers (Cucumis sativus L.) by silver ions. Euphytica 29:273-280

Edelstein, M., H.S. Paris, H. Nerson, Z. Karchi, and Y. Burger. 1985. Differential sensitivity of Cucurbita pepo cultivars to ethephon. Cucurbit Genet. Coop. Rpt. 8:67-68.
George, R.A.T. 1985. Vegetable seed production, p. 180. Longman, New York.

Nitsch, J.P., E.B. Kurtz, Jr., J.L. Liverman, and F.W. Went. 1952. The development of sex expression in cucurbit flowers. Amer. J. Bot. 39:32-43.

Peirce, L.C. 1987. Vegetables: characteristics, production and marketing, p. 374. Wiley, New York.

Rudich, J., A.H. Halevy, and N. Kedar. 1969. Increase in femaleness of three cucurbits by treatment with ethrel, an ethylene releasing compound. Planta 86:69-76.

Stermer, B.A. and R. Hammerschmidt. 1985. The induction of disease resistance by heat shock, p. 291-302. In: Cellular and molecular biology of plant stress UCLA Symp. Mol. Cell. Biol. Vol. 22.

Wien, H.C., S.C. Stapleton, D.N. Maynard, C. McClurg, and D. Riggs. 2004. Flowering, sex expression and fruiting of pumpkin (Cucurbita sp.) cultivars under various temperatures in greenhouse and distant field trials. HortScience. 39:239-242. 